\title{
Characteristics of Particulate Matter and Volatile Organic Compound Emissions from the Combustion of Waste Vinyl
}

\author{
Mona Loraine M. Barabad ${ }^{1,2}$, Wonseok Jung ${ }^{1}$, Michael E. Versoza ${ }^{1,2}$, Yong-il Lee ${ }^{1}$, \\ Kyomin Choi ${ }^{1}$ and Duckshin Park ${ }^{1, * \text { (D) }}$ \\ 1 Korea Railroad Research Institute, Uiwang City 437-757, Korea; mlmbarabad@gmail.com (M.L.M.B.); \\ worship611@krri.re.kr (W.J.); mikeverz23@krri.re.kr (M.E.V.); freego83@krri.re.kr (Y.-i.L.); \\ kmchoi@krri.re.kr (K.C.) \\ 2 Railway System Engineering, University of Science and Technology, Daejeon City 34113, Korea \\ * Correspondence: dspark@krri.re.kr; Tel.: +82-10-3343-2862
}

Received: 30 April 2018; Accepted: 27 June 2018; Published: 2 July 2018

\begin{abstract}
Vinyl samples were burned in a controlled environment to determine the characteristics of particulate matter (PM) and volatile organic compound (VOC) emissions during the combustion process. Open burning of plastic or vinyl products poses several environmental and health risks in developed and developing countries, due to the release of high concentrations of harmful pollutants. The production of fine and ultrafine particles was significant. At a heat flux of $25 \mathrm{~kW} / \mathrm{m}^{2}$, the production of PM of $0.35 \mu \mathrm{m}$ in size was highest at $63.0 \mu \mathrm{g} / \mathrm{m}^{3}$. In comparison, at fluxes of 35 and $50 \mathrm{~kW} / \mathrm{m}^{2}$, the production of PM of $0.45 \mu \mathrm{m}$ in size was highest with values of 67.8 and $87.7 \mu \mathrm{g} / \mathrm{m}^{3}$, respectively. Benzene, acetone, and other toxic compounds were also identified in the analyses.
\end{abstract}

Keywords: combustion; emission; PM; VOCs; waste vinyl

\section{Introduction}

According to the World Bank and Organization for Economic Cooperation and Development (OECD), countries generate 572 million tons of solid waste annually at an average of $2.2 \mathrm{~kg} /$ person/day (range 1.1-3.7) [1]. Projections for each country have been made based on the expected gross domestic product (GDP), and generation of average municipal solid waste (MSW), which are related to income level (IEA Annual Energy Outlook, 2005). Due to the increase in plastic utilization, open garbage burning occurs in areas where collection and organized waste handling measures are not implemented or are inadequate, even in urban areas, including backyard burning and open dump burning in developing countries [2,3]. In developed countries, open garbage burning is usually done in the backyards of houses in rural areas [4]. The World Bank reported that MSW has been used as fuel. Plastic, which is one waste component, comprised 0.9-9.5\% of the waste in China in 1993 and $4.9 \%$ in Manila in 1997 [5]. China is a region of great concern for open burning, as it is estimated to have among the highest levels of total waste production and emissions [6]. In Tanzania, large amounts of plastic waste are commonly dumped in landfills and about $60 \%$ of the domestic solid waste is subjected to open burning daily [7]. According to the United States Environmental Protection Agency (USEPA), greenhouse gases (GHG) such as carbon dioxide ( $82 \%$ of all GHG emissions in the United States in 2015) are released from the incineration of municipal waste. Garbage burning is also a major source of particulate chloride and particulate matter smaller than $2.5 \mu \mathrm{m}$ in size $\left(\mathrm{PM}_{2.5}\right)$ in Mexico City [2]. Furthermore, it is the main global source of dioxins and several other air pollutants [8].

Burning plastics release high concentrations of extractable organic compounds that cause various problems in developing and developed countries. Open waste burning poses environmental and 
health risks to those who are exposed to the smoke. In India, landfills are notable threats, as large amounts of plastic were burned and dumped with other wastes, contributing to GHG emissions [9]. Human Rights Watch (HRW) in Lebanon reported several cases of people suffering from respiratory issues including chronic obstructive pulmonary disease (COPD), coughing, throat irritation and asthma due to inhalation of smoke from the open burning of waste [10]. It has been reported that those living near incinerators have a higher prevalence of respiratory syndromes [11], such as asthma in children in Sydney, Australia [12], and chronic exposure to waste incinerators increases cancer of the larynx [13]. The USEPA also reported that the release of particulate matter (PM) through trash burning can cause deterioration in individuals with pre-existing conditions such as bronchitis, asthma, and emphysema [14]. In addition, backyard burning releases pollutants at ground level. Thus, dilution by dispersion is minimal, which may result in accumulation of pollution near the source and high measured concentrations of pollutants (e.g., dioxins) [15,16]. A detailed summary describing the health effects of waste incineration has been published and stated that ambient concentrations of various pollutants (from waste burning) could pose health risks [17].

Particulate matter less than $10 \mu \mathrm{m}$ diameter $\left(\mathrm{PM}_{10}\right)$ is produced by the burning of waste and vinyl materials. This study determined the characteristics of $\mathrm{PM}_{10}$ and ultrafine particles produced during the combustion of vinyl in a controlled environment (cone calorimeter). Harmful compounds were also assessed, including the different volatile organic compounds (VOCs) emitted in the process.

\section{Materials and Methods}

Figure 1 shows a schematic diagram of the experimental set-up. A dual-cone calorimeter was used to examine the production of PM and VOCs from vinyl samples burned at different temperatures. The specifics of the burning process using the cone calorimeter were given in our previous study [18]. The cone-shaped radiating electric heater can emit up to $100 \mathrm{~kW} / \mathrm{m}^{2}$. In this study, the strength of the electric heater was set to 25,35 , and $50 \mathrm{~kW} / \mathrm{m}^{2}$; the radiation strength of the heater was based on ISO-5660-1 as a test of the reaction to fire (heat release, smoke production, and mass loss rate). Part 1 specifically describes the HRR (heat release rate; cone calorimeter method) and smoke production rate (dynamic measurement). The mass remaining, as well as $\mathrm{O}_{2}, \mathrm{CO}$ and $\mathrm{CO}_{2}$ produced at different temperatures, were measured.

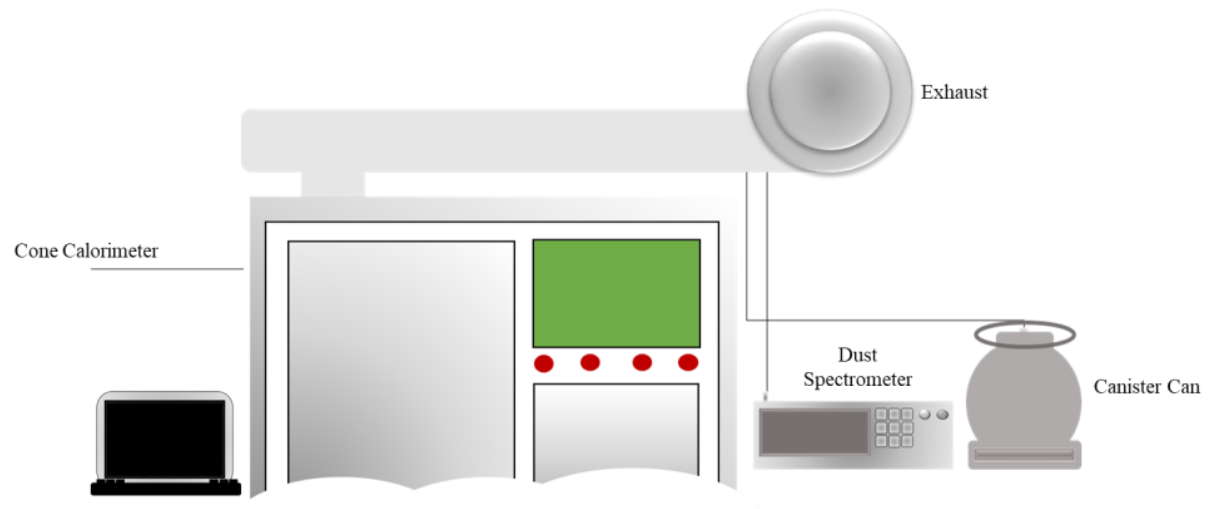

Figure 1. Schematic diagram showing the experimental set-up of the dual-cone calorimeter.

The plastic sample was collected in a rural village near Andong, a small city in South Korea. Low-density polyethylene (LDPE) plastic film is used for farming in villages. This type of waste is categorized as agricultural waste, which is collected and processed either through landfilling, recycling or incineration. Depending on the burning conditions and parameters set, a series of 2-3 burn cycles were carried out at each temperature. Vinyl samples weighing approximately $10 \mathrm{~g}$ were cut and positioned inside the sample holder, which measured $100 \times 100 \times 36 \mathrm{~mm}^{3}(\mathrm{~W} \times \mathrm{L} \times \mathrm{H})$, balanced and then a final weighed was recorded. During the test, aluminum foil was placed around the holder 
and gas analyzers $\left(\mathrm{N}_{2}, \mathrm{CO}, \mathrm{CO}_{2}\right.$, and $\left.\mathrm{O}_{2}\right)$ before calibration. To control the initial conditions, the gas flow rate and concentration were also monitored. The flow rate, the weight of burned vinyl, and other parameters were stored in the software of the cone calorimeter. To measure the size contribution, an aerosol spectrometer (GRIMM 1.129 SKY OPC) with a measurement range of 0.25 to $32 \mu \mathrm{m}$, and regulated flow rate $(6 \mathrm{~L} / \mathrm{min})$ with an external vacuum pump that was controlled by a critical orifice was used. A 6 L Restek SilcoCan stainless steel canister coated with fused silica on the inside, with its inlet aligned with the aerosol spectrometer, was used to collect compounds from the air samples. The collected pre-concentrated samples were analyzed using gas chromatography/mass spectrometry (Agilent/HP-6890; Agilent Technologies, Inc. Savage, MD, USA).

\section{Results}

Table 1 shows the different characteristics of vinyl combustion using the cone calorimeter. The average mass of the samples was 13.0, 12.7, and $12.9 \mathrm{~g}$ at heat fluxes of 25, 35, and $50 \mathrm{~kW} / \mathrm{m}^{2}$, respectively.

Table 1. Combustion variables of vinyl measured using a cone calorimeter.

\begin{tabular}{cccccccc}
\hline Heat Flux $\left(\mathbf{k W} / \mathbf{m}^{\mathbf{2}}\right)$ & Peak HRR & Mass $(\mathbf{g})+$ Foil & Remaining Mass & Mass Lost $\mathbf{( g )}$ & $\mathbf{O}_{\mathbf{2}}(\mathbf{g})$ & $\mathbf{C O}(\%)$ & $\mathrm{CO}_{2}(\%)$ \\
\hline 25 & $247.9 \pm 42.0$ & $13.0 \pm 1.2$ & $5.8 \pm 0.5$ & $7.3 \pm 1.0$ & 30 & 31 & 462.8 \\
35 & $295.3 \pm 27.6$ & $12.7 \pm 0.7$ & $5.2 \pm 0.2$ & $7.5 \pm 0.7$ & 39.6 & 7.3 & 691.8 \\
50 & $330.4 \pm 51.7$ & $12.9 \pm 0.5$ & $4.5 \pm 0.4$ & $8.3 \pm 0.2$ & 29.5 & 19.3 & 468.5 \\
\hline
\end{tabular}

Post-combustion measurements revealed that approximately $55.9 \%, 59.3 \%$, and $64.8 \%$ of the mass was removed at 25,35 , and $50 \mathrm{~kW} / \mathrm{m}^{2}$, respectively. The samples produced different amounts of $\mathrm{O}_{2}$ consumption and percentages of $\mathrm{CO}$ and $\mathrm{CO}_{2}$. $\mathrm{CO}$ production was highest at $25 \mathrm{~kW} / \mathrm{m}^{2}(31 \%)$, followed by 50 and $35 \mathrm{~kW} / \mathrm{m}^{2}$ (19.3\% and $7.3 \% \mathrm{CO}$, respectively). $\mathrm{CO}_{2}$ production was highest at 35 $\mathrm{kW} / \mathrm{m}^{2}(691.8 \%)$, followed by 50 and $25 \mathrm{~kW} / \mathrm{m}^{2}$ (468.5 and $462.8 \%$, respectively). $\mathrm{O}_{2}$ consumption was highest at $35 \mathrm{~kW} / \mathrm{m}^{2}(39.6 \mathrm{~g})$, followed by 25 and $50 \mathrm{~kW} / \mathrm{m}^{2}\left(30 \mathrm{~g}\right.$ and $29.5 \mathrm{~g}$ respectively). $\mathrm{O}_{2}$ and $\mathrm{CO}_{2}$ values were proportional, differing from those of $\mathrm{CO}$; the highest amount of $\mathrm{CO}$ was produced at $25 \mathrm{~kW} / \mathrm{m}^{2}$, and the lowest amount was produced at $35 \mathrm{~kW} / \mathrm{m}^{2}$, whereas the opposite was true for $\mathrm{O}_{2}$ and $\mathrm{CO}_{2}$. Increased oxygen consumption could lead to more combustion, which increases the release of $\mathrm{CO}_{2}$. However, when the $\mathrm{O}_{2}$ consumption rate is lower, incomplete combustion can take place, leading to soot formation. During this process, soot $(C)$ and $\mathrm{CO}_{2}$ react and generate a greater percentage of CO. The maximum HRR was $330.4 \pm 51.7$ at $50 \mathrm{~kW} / \mathrm{m}^{2}$, followed by $295.3 \pm 27.6$ at $35 \mathrm{~kW} / \mathrm{m}^{2}$ and $247.9 \pm 42.0$ at $25 \mathrm{~kW} / \mathrm{m}^{2}$. Figure 2 shows the PM size distribution and concentrations from vinyl combustion. The majority of particles had smaller sizes $\left(<\mathrm{PM}_{1}\right)$ compared to $\mathrm{PM}_{2.5}$ to $\mathrm{PM}_{10}$. At $25 \mathrm{~kW} / \mathrm{m}^{2}$, the peak PM size was $0.35 \mu \mathrm{m}\left(\right.$ at $\left.63.0 \mu \mathrm{g} / \mathrm{m}^{3}\right)$, whereas, the peak size at 35 and $50 \mathrm{~kW} / \mathrm{m}^{2}$ was $0.45 \mu \mathrm{m}$, with 67.8 and $87.7 \mu \mathrm{g} / \mathrm{m}^{3}$, respectively. In addition, $0.45 \mu \mathrm{m}$ had the highest peak concentration among all of the compounds, while $50 \mathrm{~kW} / \mathrm{m}^{2}$ obtained the highest concentrations compared to the other heat fluxes. However, there was an apparent increase in distribution from $\mathrm{PM}_{2.5}$ to $\mathrm{PM}_{8.75}$, as shown Figure 2.

The emissions factor (EF) was calculated using the following equation [15]:

$$
F\left(\frac{\mathrm{mg}}{\mathrm{kg}}\right)=\frac{\text { concentration of pollutants }\left(\frac{\mathrm{mg}}{\mathrm{m}^{3}}\right) \times \text { flowrate }\left(\frac{\mathrm{m}^{3}}{\mathrm{~min}}\right) \times \text { sampling time }(\mathrm{min})}{\text { weight of burned vinyl sample }(\mathrm{kg})}
$$

The highest EF $(\mathrm{mg} / \mathrm{kg})$ of PM in this study was for the smaller size range of $0.35-0.45 \mu \mathrm{m}$, as shown in Table 2. 


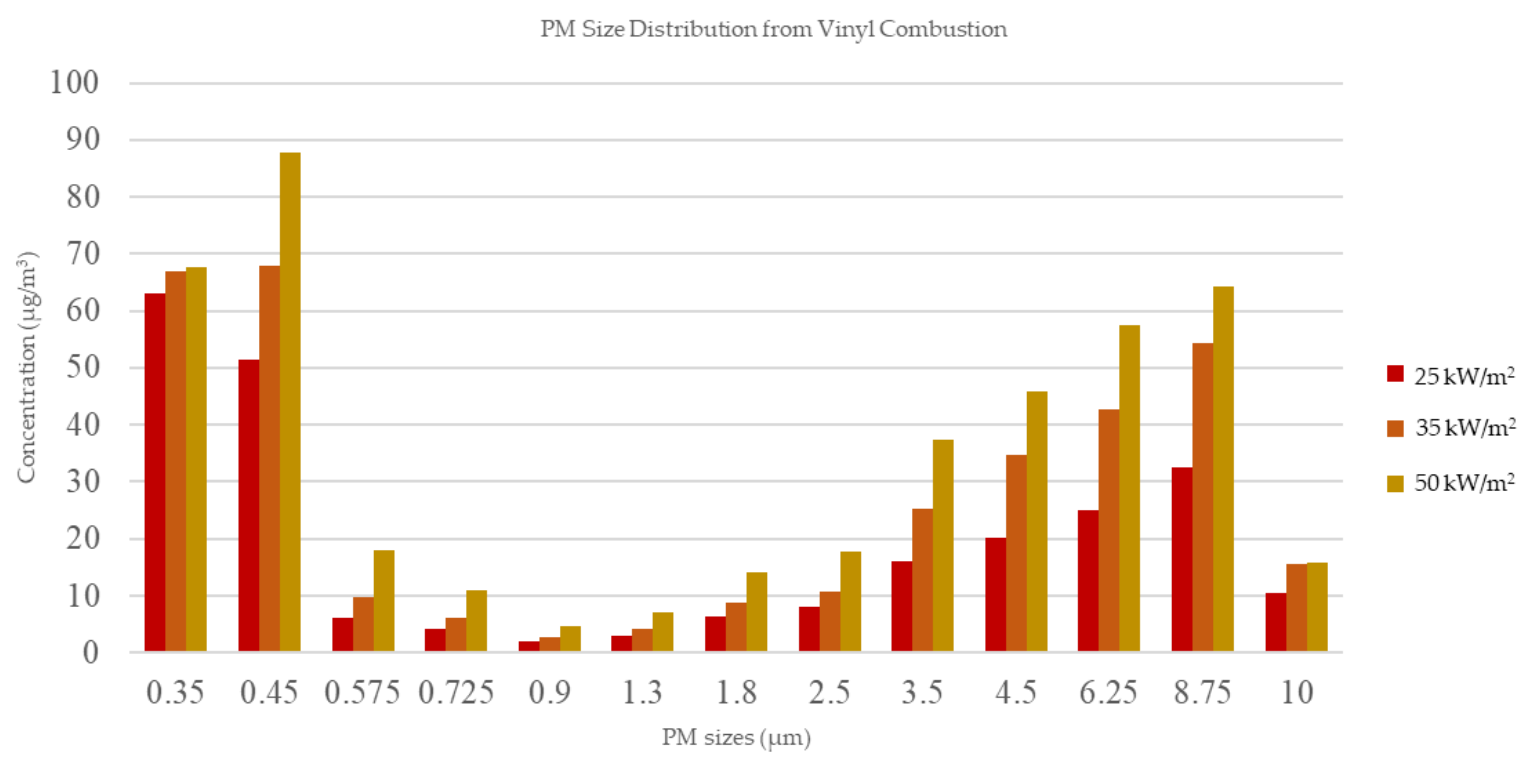

Figure 2. Particulate matter (PM) size distribution from vinyl combustion.

Table 2. The concentration of particulate matter released in the combustion of vinyl.

\begin{tabular}{cccc}
\hline $\mathbf{P M}(\boldsymbol{\mu m})$ & $\mathbf{2 5} \mathbf{~ W W} / \mathbf{m}^{\mathbf{2}}$ & $\mathbf{3 5} \mathbf{~ W W} / \mathbf{m}^{\mathbf{2}}$ & $\mathbf{5 0} \mathbf{~ W W} / \mathbf{m}^{\mathbf{2}}$ \\
\hline 0.35 & $50.4 \pm 5.2$ & $53.5 \pm 1.3$ & $54.1 \pm 1.0$ \\
0.45 & $41.2 \pm 11.0$ & $54.3 \pm 1.5$ & $70.2 \pm 1.2$ \\
0.57 & $4.9 \pm 1.6$ & $7.8 \pm 1.0$ & $14.5 \pm 2.0$ \\
0.725 & $3.3 \pm 1.0$ & $4.8 \pm 0.5$ & $9.0 \pm 1.0$ \\
0.9 & $1.5 \pm 0.5$ & $2.1 \pm 0.3$ & $4.0 \pm 0.2$ \\
1.3 & $2.5 \pm 1.0$ & $3.4 \pm 0.5$ & $6.0 \pm 1.0$ \\
1.8 & $5.0 \pm 1.5$ & $7.0 \pm 1.3$ & $11.2 \pm 1.3$ \\
2.5 & $6.4 \pm 2.0$ & $8.7 \pm 1.5$ & $14.2 \pm 1.1$ \\
3.5 & $13.0 \pm 3.0$ & $20.3 \pm 2.3$ & $30.0 \pm 3.2$ \\
4.5 & $16.2 \pm 5.0$ & $28.0 \pm 4.2$ & $37.0 \pm 3.4$ \\
6.25 & $20.0 \pm 8.3$ & $34.2 \pm 5.2$ & $46.0 \pm 6.2$ \\
8.75 & $26.0 \pm 8.3$ & $43.4 \pm 11.0$ & $51.5 \pm 9.1$ \\
10 & $8.4 \pm 3.3$ & $12.5 \pm 6.2$ & $12.7 \pm 3.0$ \\
\hline
\end{tabular}

At $25 \mathrm{~kW} / \mathrm{m}^{2}, 0.35 \mu \mathrm{m}$ particles had an EF of $50.4 \pm 5.2 \mathrm{mg} / \mathrm{kg}$, whereas, at 35 and $50 \mathrm{~kW} / \mathrm{m}^{2}$, $0.45 \mu \mathrm{m}$ particles had the highest EF, at $54.3 \pm 1.5$ and $70.2 \pm 1.2 \mathrm{mg} / \mathrm{kg}$, respectively. At a heat flux of $50 \mathrm{~kW} / \mathrm{m}^{2}$, the majority of PM emissions from the vinyl combustion analysis ranged from less than $\mathrm{PM}_{1}$ to $\mathrm{PM}_{10}$.

Figure 3 shows the concentrations of VOCs from vinyl combustion at different temperatures. Of the compounds detected, benzene was the most common, comprising 30.7\%, 38.3\%, and 34.4\% at 25,35 , and $50 \mathrm{~kW} / \mathrm{m}^{2}$, respectively. Acetone comprised $26.0 \%, 11.2 \%$, and $20.0 \%$ at 25,35 , and $50 \mathrm{~kW} / \mathrm{m}^{2}$. Isopropyl alcohol was only produced with heat fluxes of 35 and $50 \mathrm{~kW} / \mathrm{m}^{2}$, comprising $20.0 \%$ and $9.6 \%$, respectively. By contrast, methyl ethyl ketone comprised $7.3 \%$ and $4.4 \%$ of the total at 25 and $35 \mathrm{~kW} / \mathrm{m}^{2}$, respectively. 2-Hexaneone comprised $10.0 \%, 4.2 \%$, and $2.3 \%$ for 25,35 , and $50 \mathrm{~kW} / \mathrm{m}^{2}$, respectively, whereas toluene comprised $6.2 \%, 4.2 \%$, and $4.4 \%$. Table 3 shows the VOCs emitted in vinyl combustion and the results also varied with the heat fluxes.

The concentrations of a few of the compounds produced exceeded $100 \mathrm{mg} / \mathrm{kg}$. Benzene comprised $277.8 \pm 14.6,479.8 \pm 19.4$, and $320.0 \pm 22.5 \mathrm{mg} / \mathrm{kg}$ at fluxes of 25,35 , and $50 \mathrm{~kW} / \mathrm{m}^{2}$, respectively; followed by acetone at $232.0 \pm 34.2,140.0 \pm 16.6$, and $184.5 \pm 35.0 \mathrm{mg} / \mathrm{kg}$. The production of isopropyl alcohol also exceeded $100 \mathrm{mg} / \mathrm{kg}$, but only at a flux of $35 \mathrm{~kW} / \mathrm{m}^{2}$ with $250.8 \pm 24.0$. Several compounds exceeded $50 \mathrm{mg} / \mathrm{kg}$ at selected fluxes, including isopropyl alcohol at $50 \mathrm{~kW} / \mathrm{m}^{2}$, methyl ethyl ketone at 
25 and $35 \mathrm{~kW} / \mathrm{m}^{2}$, 2-hexaneone at 25 and $35 \mathrm{~kW} / \mathrm{m}^{2}$, and toluene at all three heat fluxes. Some other compounds were produced in lesser amounts or were not detected as shown in Table 4.

Table 3. Experimental results $\left(\mathrm{ug} / \mathrm{m}^{3}\right)$ of VOC from vinyl combustion.

\begin{tabular}{|c|c|c|c|}
\hline Compounds & $25 \mathrm{~kW} / \mathrm{m}^{2}$ & $35 \mathrm{~kW} / \mathrm{m}^{2}$ & $50 \mathrm{~kW} / \mathrm{m}^{2}$ \\
\hline Acetone & 290.05 & 174.94 & 230.65 \\
\hline Isopropyl alcohol & 17.10 & 313.45 & 111.81 \\
\hline Methyl ethyl ketone & 82.72 & 68.67 & ND \\
\hline Ethyl acetate & 11.60 & 21.20 & 21.73 \\
\hline Hexane & 18.57 & 14.75 & 4.53 \\
\hline Tetrahydrofuran & 26.17 & 16.54 & 31.03 \\
\hline Benzene & 347.25 & 599.79 & 400.02 \\
\hline Heptane & 17.60 & 4.11 & 3.21 \\
\hline Methyl isobutyl ketone & 3.60 & 4.20 & ND \\
\hline Toluene & 70.03 & 65.76 & 50.94 \\
\hline 2-Hexaneone & 112.90 & 66.19 & 24.93 \\
\hline Ethylbenzene & 9.16 & 8.99 & 5.05 \\
\hline$m, p$-Xylene & 0.882 & 28.74 & 1.32 \\
\hline Styrene & 31.043 & 33.88 & 19.39 \\
\hline$o$-Xylene & 2.97 & 7.14 & 43.27 \\
\hline 4-Ethyltoluene & 5.65 & 0.52 & 12.56 \\
\hline 1,3,5-Trimethylbenzene & 4.64 & 12.83 & 10.54 \\
\hline 1,2,4-Trimethylbenzene & 14.45 & 22.64 & 40.95 \\
\hline Benzyl chloride & ND & 3.25 & 4.04 \\
\hline 1,4-Dichlorobenzene & 1.30 & 3.71 & 7.49 \\
\hline 1,3-Dichlorobenzene & 6.97 & 11.60 & 25.67 \\
\hline 1,2-Dichlorobenzene & 3.01 & 7.20 & 9.68 \\
\hline 1,2,4-Trichlorobenzene & 44.03 & 74.51 & 47.92 \\
\hline Hexachloro-1,3-butadiende & 10.06 & ND & 54.71 \\
\hline Total: & 1131.77 & 1564.62 & 1161.43 \\
\hline
\end{tabular}

ND. Not Detected.

VOC emission from vinyl combustion

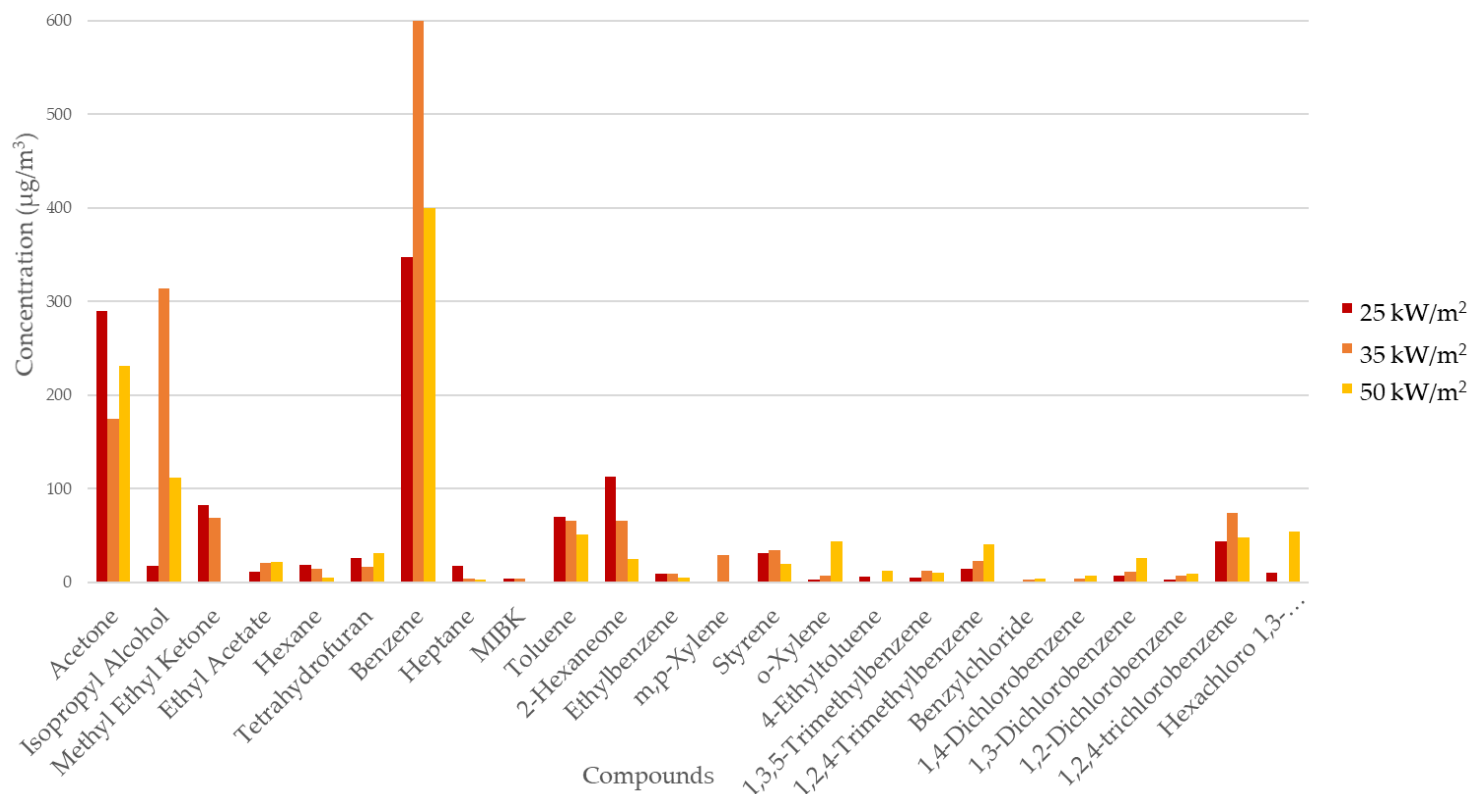

Figure 3. Volatile organic compound emissions from vinyl combustion. 
Table 4. Emission factors ( $\mathrm{mg} / \mathrm{kg}$ ) of VOCs from the combustion of vinyl.

\begin{tabular}{|c|c|c|c|}
\hline Compounds & $25 \mathrm{~kW} / \mathrm{m}^{2}$ & $35 \mathrm{~kW} / \mathrm{m}^{2}$ & $50 \mathrm{~kW} / \mathrm{m}^{2}$ \\
\hline Acetone & $232.0 \pm 34.2$ & $140.0 \pm 16.6$ & $184.5 \pm 35.0$ \\
\hline Isopropyl Alcohol & $13.4 \pm 4.9$ & $250.8 \pm 2.4$ & $89.4 \pm 11.3$ \\
\hline Methyl Ethyl Ketone & $66.2 \pm 14.0$ & $54.9 \pm 8.0$ & ND \\
\hline Ethyl Acetate & $9.3 \pm 1.7$ & $17.0 \pm 2.8$ & $17.4 \pm 0.3$ \\
\hline Hexane & $14.9 \pm 2.1$ & $11.8 \pm 1.4$ & $3.6 \pm 0.6$ \\
\hline Tetrahydrofuran & $20.9 \pm 0.3$ & $13.2 \pm 2.9$ & $24.8 \pm 4.9$ \\
\hline Benzene & $277.8 \pm 14.6$ & $479.8 \pm 19.4$ & $320.0 \pm 22.5$ \\
\hline Heptane & $14.1 \pm 1.9$ & $3.3 \pm 0.4$ & $2.6 \pm 0.4$ \\
\hline MIBK & $2.9 \pm 0.4$ & $3.4 \pm 0.4$ & ND \\
\hline Toluene & $56.0 \pm 3.6$ & $52.6 \pm 3.4$ & $40.8 \pm 2.5$ \\
\hline 2-Hexaneone & $90.3 \pm 14.7$ & $53.0 \pm 1.2$ & $19.9 \pm 1.5$ \\
\hline Ethylbenzene & $7.3 \pm 0.9$ & $7.2 \pm 0.8$ & $4.0 \pm 0.0$ \\
\hline m,p-Xylene & $0.7 \pm 0.1$ & $23.0 \pm 0.8$ & $1.1 \pm 0.3$ \\
\hline Styrene & $24.8 \pm 4.8$ & $27.1 \pm 5.4$ & $15.5 \pm 2.4$ \\
\hline o-Xylene & $2.4 \pm 0.4$ & $5.7 \pm 0.4$ & $34.6 \pm 12.7$ \\
\hline 4-Ethyltoluene & $4.5 \pm 0.4$ & $0.4 \pm 0.1$ & $10.0 \pm 2.1$ \\
\hline 1,3,5-Trimethylbenzene & $3.7 \pm 0.6$ & $10.3 \pm 2.3$ & $8.4 \pm 2.6$ \\
\hline 1,2,4-Trimethylbenzene & $11.6 \pm 1.0$ & $18.1 \pm 2.1$ & $32.8 \pm 3.8$ \\
\hline Benzylchloride & ND & $2.6 \pm 0.2$ & $3.2 \pm 0.4$ \\
\hline 1,4-Dichlorobenzene & $1.0 \pm 0.2$ & $3.0 \pm 0.7$ & $6.0 \pm 1.1$ \\
\hline 1,3-Dichlorobenzene & $5.6 \pm 0.5$ & $9.3 \pm 1.5$ & $20.5 \pm 2.0$ \\
\hline 1,2-Dichlorobenzene & $2.4 \pm 0.3$ & $5.8 \pm 1.1$ & $7.7 \pm 1.4$ \\
\hline 1,2,4-trichlorobenzene & $35.2 \pm 1.6$ & $59.6 \pm 2.5$ & $38.3 \pm 4.9$ \\
\hline $\begin{array}{c}\text { Hexachloro } \\
\text { 1,3-Butadiende }\end{array}$ & $8.0 \pm 0.6$ & $0.0 \pm 1.4$ & $43.8 \pm 2.4$ \\
\hline
\end{tabular}

ND. Not Detected.

\section{Discussion}

Burning of waste is a source of air pollutants [19] that potentially contribute to environmental and health problems. Emission characteristics associated with the combustion of vinyl differ according to various parameters. In the current study, PM and VOC emissions from the cone calorimeter varied by combustion temperature. CO levels were lower compared to a study conducted in Mexico City, in which different plastic materials (e.g., bottles, bags, buckets) collected from several urban areas were burned; high emissions of $\mathrm{CO}$ were detected, which likely resulted from the burning of a high proportion of ethylene-based plastic polymers [20]. According to Font et al., CO emissions are affected by temperature; thus, when the temperature increases, carbon oxides decrease [21]. CO values were highest when a heat flux of $25 \mathrm{~kW} / \mathrm{m}^{2}$ was applied. In addition, according to Lindholm et al., $\mathrm{CO}$ is a result of incomplete combustion and can be a major product if flame retardants disrupted the burning process [22].

In this study, PM emission characteristics were measured in a controlled environment. Of the analyzed particles, ultrafine particles $\left(<\mathrm{PM}_{1}\right)$ occurred at the highest concentration. The total percentages (\%) emitted from particles ranging in size from $0.35 \mu \mathrm{m}$ to $0.9 \mu \mathrm{m}$ were $53.3,64.5$, and 79.6 , explaining the greater concentration of smaller-sized particles with heat fluxes of 25,35 and $50 \mathrm{~kW} / \mathrm{m}^{2}$, respectively. The total $\mathrm{PM}_{10}$ concentration produced at heat fluxes of 25,35 , and $50 \mathrm{~kW} / \mathrm{m}^{2}$ was 237.6 , 334.0, and $433.1 \mu \mathrm{g} / \mathrm{m}^{3}$, respectively. In this study, the characteristics of $\mathrm{PM}_{10}$ and $\mathrm{PM}_{2.5}$ can be compared to those in previous work that studied emissions from the combustion of plastic products. One study reported that $20.6 \mathrm{mg} / \mathrm{g}(0.020573 \mathrm{mg} / \mathrm{kg})$ of $\mathrm{PM}_{2.5}$ was collected from a single waste incinerator [23]. This value was lower compared to our results, where we observed values of 190.1, 267.2 , and $346.5 \mathrm{mg} / \mathrm{kg}$ with heat fluxes of 25,35 , and $50 \mathrm{~kW} / \mathrm{m}^{2}$, respectively. However, other research estimated emission amounts of about $10.5 \pm 8.8 \mathrm{~g} / \mathrm{kg}$ [17] and $11.3 \pm 7.5 \mathrm{~g} / \mathrm{kg}$ [7], roughly 10 times higher than our values, which might be due to the larger sample area and amount of the materials used in that experiment. 
We also characterized VOC emissions and found that notable compounds were produced. The highest concentration of total VOC (TVOC) was obtained at a heat flux of $35 \mathrm{~kW} / \mathrm{m}^{2}$ $\left(1564.6 \mu \mathrm{g} / \mathrm{m}^{3}\right)$. Results at 50 and $25 \mathrm{~kW} / \mathrm{m}^{2}$ were similar $\left(1161.4\right.$ and $1131.8 \mu \mathrm{g} / \mathrm{m}^{3}$, respectively). Benzene contributed the highest concentration to TVOC at 25,35 , and $50 \mathrm{~kW} / \mathrm{m}^{2}$. Lemieux et al. summarized the test data generated by application of recyclers and non-recyclers for burning waste [24]. Emission products of benzene, acetone and styrene were all significant and higher than the values in our study. Styrene comprised only $2.7 \%, 2.7 \%$, and $1.2 \%$ of the TVOC collected with heat fluxes of 25,35 and $50 \mathrm{~kW} / \mathrm{m}^{2}$, respectively. In addition, another study described 1,3,5 triphenylbenzene as a useful marker of the burning of plastic products in domestic waste and litter [25]; however, 1,3,5 triphenylbenzene was barely detected in our study.

Our research was conducted in the context of a controlled laboratory set-up. Several parameters were closely regulated; hence, the results may differ from actual burning conditions (i.e., open/barrel burning). Emissions from open burning can be several orders of magnitude higher compared to those of controlled combustion [24]. The results from this study presented that the heatflux characteristics could be a notable factor in the size distribution and concentration. The greatest concentrations found in this study were from ultrafine to fine particles. However, at the temperatures applied, we also observed an increase in concentrations of particles in the range of PM $3.5 \mu \mathrm{m}$ to $8.75 \mu \mathrm{m}$, this trend was observed from all heatfluxes. PM emission and size distribution largely depends on the combustion conditions, where fast pyrolysis and high combustion temperatures may cause incomplete combustion [19]. Flame residence time [25] is another factor that can determine the emission products arising from incomplete combustion. To achieve complete combustion, gases produced must remain in the high-temperature zone of the furnace for a minimum residence time of 1-2 s [17]. The study can assume that when the plastic sample was under a combustion process, ultrafine and $\mathrm{PM}_{10}$ released with significant results. At temperatures between 700 to $800{ }^{\circ} \mathrm{C}$, benzene and toluene were produced in significant amounts from the combustion of polyethylene (e.g., garbage bags, grain storage bags, and shopping bags) [26]. In contrast, some oxygenated compounds have also been identified in combustion experiments at low temperature [21]. Thus, temperature influences the characteristics of the particles and compounds emitted from the combustion process. However, here, the highest recorded concentration of benzene was emitted at a heat flux of $35 \mathrm{~kW} / \mathrm{m}^{2}$, which was neither the lowest nor the highest temperature used in this experiment. Although this research applied different heat fluxes, the characteristics of the temperature were not taken into consideration. Furthermore, flame residence time and the characteristics of the vinyl used in the combustion process were also not examined in detail.

Several ways of waste handling have been implemented in different countries. Developed countries apply methods such as recycling, incinerating, and discarding in landfills. Presently, as the Korean economy is rapidly growing, the immense amount of industrial waste produced is also increasing. Waste management in South Korea comprises several methods, of which incineration is one. Incineration is used to increase renewable energy production and to make use of non-recyclable and non-combustible waste (wet organic waste) [27,28]. Furthermore, incineration (in commercial incinerators, furnaces, etc.) plays an important role in industrial-waste energy production through heat energy recovery [28]. However, this study aimed to investigate the burning of plastic film, especially in the backyard context. Although household waste was reported to make up approximately $15 \%$ of the total amount of waste produced in South Korea, it is a significant target for renewable energy production. Overall, $17 \%$ (3.04 Mt) of household waste was incinerated, while recycling $(57 \%)$ and landfilling $(26 \%)$ were also utilized for waste management $[28,29]$. The Korean government introduced the volume-based waste fee (VBWF) system in 1995, in which local cities have a responsibility to collect, recycle, and treat solid waste from households, and small and large businesses. This method helped reduce waste generation and improved recycling in the MSW sector [30]. Another study investigated the removal efficiency of PM from furnaces. $\mathrm{PM}_{10}$ and $\mathrm{PM}_{2.5}$ were the primary particles produced, with coarse particles more effectively removed compared 
to fine particles [31]. However, developing countries are still practicing open burning and waste dumping due to inadequate disposal technology. Plastics are combustible and can result in hazardous emissions when burned in an uncontrolled environment [3]. During waste combustion, suspension of PM due to dispersion is decreased, which contributes to high concentrations of toxic pollutants. Poor dispersion of emissions will lead to an increase in direct inhalation [24], which impacts both the ambient environment and human health.

\section{Conclusions}

Open burning of plastic and plastic related materials is still widely practiced in several countries because of poor waste handling. Here, we burned vinyl samples under controlled laboratory conditions using a cone calorimeter and analyzed the characteristics of the various pollutants emitted.

We observed significant differences between the abundance of $\mathrm{PM}_{10}$ and $\mathrm{PM}_{2.5}$. The most abundant particle size was in the ultrafine range $\left(<\mathrm{PM}_{1}\right)$. The smallest-sized particles $(0.35$ and $0.45 \mu \mathrm{m})$ constituted the greatest percentage of total PM emissions. Many journals have reported the characteristics of $\mathrm{PM}_{10}$ and $\mathrm{PM}_{2.5}$ emitted from waste or plastic burning. However, our investigation found that the concentration and emission characteristics of ultrafine particles were significant, which may be useful for future reference. Toxic by-products were also produced from the combustion process, including several VOCs, such as benzene, acetone, and isopropyl, which were dominant compared to other VOCs identified.

We identified several limitations to our methodology; thus, our results may differ from those observed under actual burning conditions (i.e., garbage or open barrel burning). However, we showed that coarse, ultrafine/fine particles and carcinogenic compounds were emitted under laboratory conditions. Exposure to these pollutants may cause environmental and health issues. Although different methods of waste management have been introduced in various countries, a lack of knowledge of the end products emitted represents a hindrance to successful management. Therefore, raising public awareness of proper methods of garbage disposal is necessary.

Author Contributions: D.S.P. and W.S.J. designed the experiment; M.L.M. Barabad and W.S.J. implemented the experimental process; M.L.M.B. and M.V. analyzed the data; D.S.P., W.S.J., Y.-i.L. and K.M.C. contributed the materials and tools for the experiment; M.L.M.B. wrote the manuscript.

Funding: This research was supported by a grant from the R\&D Program of the Korea Railroad Research Institute, Republic of Korea. This research received no external funding.

Conflicts of Interest: The authors declare no conflicts of interest

\section{References}

1. World Bank. Urban Development Series-Knowledge Paper. Available online: https://siteresources. worldbank.org/INTURBANDEVELOPMENT/Resources/336387--1334852610766/What_a_Waste2012_ Final.pdf (accessed on 4 March 2018).

2. Li, G.; Lei, W.; Bei, N.; Molina, L.T. Contribution of garbage burning to chloride and $\mathrm{PM}_{2.5}$ in Mexico City. Atmos. Chem. Phys. 2012, 12, 8751-8761. [CrossRef]

3. Estrellan, C.R.; Iino, F. Toxic emissions from open burning. Chemosphere 2010, 80, 193-207. [CrossRef] [PubMed]

4. USEPA. An Inventory of Sources and Environmental Releases of Dioxin-Like Compounds in the United States for the Years 1987, 1995, and 2000; EPA/600/P-03/002F; National Center for Environmental Assessment, Office of Research and Development: Washington, DC, USA, 2006; p. 677.

5. Rand, T.; Haukohl, J.; Marxen, U. Municipal Solid Waste Incineration: A Decision Maker's Guide; The World Bank: Washington DC, USA, 2000; Available online: http:/ / siteresources.worldbank.org/INTUSWM/Resources / 463617-1202332338898/incineration-dmg.pdf (accessed on 4 March 2018).

6. Wiedinmyer, C.; Yokelson, R.J.; Gullet, B.K. Global emissions of trace gases, particulate matter, and hazardous air pollutants from open burning of domestic waste. Environ. Sci. Technol. 2014, 48, 9523-9530. [CrossRef] [PubMed] 
7. Kassim, S.M. Sustainability of Private Sector in Solid Waste Collection: A Case of Dar es Salaam Tanzania. 2006. Available online: https://dspace.lboro.ac.uk/2134/2336 (accessed on 23 April 2018).

8. Lemieux, P.M.; Lutes, C.C.; Abbott, J.A.; Aldous, K.M. Emissions of polychlorinated dibenzo- $p$-dioxins and polychlorinated dibenzofurans from the open burning of household waste in barrels. Environ. Sci. Technol. 2000, 34, 377-384. [CrossRef]

9. Verma, R.; Vinoda, K.S.; Papireddy, M.; Gowda, A.N.S. Toxic pollutants from plastic waste-A review. Procedia Environ. Sci. 2016, 35, 701-708. [CrossRef]

10. Human Rights Watch: "As if You're Inhaling Your Death". The Health Risks of Burning Waste in Lebanon. 2017. Available online: https://www.hrw.org/sites/default/files/report_pdf/lebanon1117_web_1.pdf (accessed on 23 April 2018).

11. Wang, J.Y.; Hsiue, T.R.; Chen, H.I. Bronchial responsiveness in an area of air pollution resulting from wire reclamation. Arch. Dis. Child. 1992, 67, 488-490. [CrossRef] [PubMed]

12. Gray, E.J.; Peat, J.K.; Mellis, C.M.; Harrington, J.; Woolcock, A.J. Asthma severity and morbidity in a population sample of Sydney school children: Part I-Prevalence and effect of air pollutants in coastal regions. Aust. N. Z. J. Med. 1994, 24, 168-175. [CrossRef] [PubMed]

13. Fingerhut, M.A.; Halperin, W.E.; Marlow, D.A.; Piacitelli, L.A.; Honchar, P.A.; Sweeney, M.H.; Greife, A.L.; Dill, P.A.; Steenland, K.; Suruda, A.J. Cancer mortality in workers exposed to 2,3,7,8-tetrachlorodibenzo-p-dioxin. N. Engl. J. Med. 1991, 324, 212-218. [CrossRef] [PubMed]

14. EPA Web Archives. Available online: https://archive.epa.gov/epawaste/nonhaz/municipal/web/html/ index-3.html (accessed on 16 April 2018).

15. National Air Quality Management Programme. Air Pollution Dispersion and Topographical Effects; Publication Series B: Book 7 of National Air Quality Management Programme Phase II Transition Project, Air Quality Management \& Climate Change; Department of Environmental Affairs and Tourism Environmental Quality and Protection Chief Directorate: Pretoria, South Africa, 2016; p. 1.

16. Wevers, M.; De Fre, R.; Desmedt, M. Effect of backyard burning on dioxin deposition and air concentrations. Chemosphere 2004, 54, 1351-1356. [CrossRef]

17. Understanding Health Effects of Incineration-Waste Incineration and Public Health (NCBI Bookshelf); National Academies Press: Washington, DC, USA, 2000. [CrossRef]

18. Park, D.S.; Barabad, M.L.; Lee, G.J.; Kwon, S.B.; Cho, Y.M.; Lee, D.H.; Cho, K.C.; Lee, K.Y. Emission characteristics of particulate matter and volatile organic compounds in cow dung combustion. Environ. Sci. Technol. 2013, 47, 12952-12957. [CrossRef] [PubMed]

19. Maasikmets, M.; Kupri, H.-L.; Teinemaa, E.; Vainumae, K.; Arumae, T.; Roots, O.; Kimmel, V. Emissions from burning municipal solid waste and wood in domestic heaters. Atmos. Pollut. Res. 2016, 7, 438-446. [CrossRef]

20. Christian, T.J.; Yokelson, R.J.; Cardenas, B.; Molina, L.T.; Engling, G.; Hsu, S.-C. Trace gas and particle emissions from domestic and industrial biofuel use and garbage burning in central Mexico. Atmos. Chem. Phys. 2010, 10, 565-584. [CrossRef]

21. Font, R.; Aracil, I.; Fullana, A.; Conesa, J.A. Semivolatile and volatile compounds in combustion of polyethylene. Chemosphere 2004, 57, 615-627. [CrossRef] [PubMed]

22. Lindholm, J.; Brink, A.; Hupa, M. Cone Calorimeter-A Tool for Measuring Heat Release Rate. Available online: http:/ / www.ffrc.fi/FlameDays_2009/4B/LindholmPaper.pdf (accessed on 6 June 2018).

23. Yan, F.; Zhu, F.; Wang, Q.; Xiong, Y. Preliminary study of PM2.5 formations during the municipal solid waste incineration. Procedia Environ. Sci. 2016, 31, 475-481. [CrossRef]

24. Lemieux, P.M. Evaluation of Emissions from the Open Burning of Household Waste in Barrels: Volume 1. Technical Report; U.S. Environmental Protection Agency, National Risk Management Research Laboratory: Washington, DC, USA, 1997; 70p.

25. Simoneit, B.R.T.; Medeiros, P.M.; Didyk, B.M. Combustion products of plastics as indicators for refuse burning in the atmosphere. Environ. Sci. Technol. 2005, 39, 6961-6970. [CrossRef] [PubMed]

26. Font, R.; Aracil, I.; Fullana, A.; Gullon, I.M.; Conesa, J.A. Semivolatile compounds in pyrolysis of polyethylene. J. Anal. Appl. Pyrolysis 2003, 68-69, 599-611. [CrossRef]

27. Ministry of Environment. Waste in Energy Strategic Plan; Ministry of Environment: Gwacheon, Korea, 2008. (In Korean) 
28. Ryu, C. Potential of municipal solid waste for renewable energy production and reduction of Greenhouse gas emissions in South Korea. J. Air Waste Manag. Assoc. 2010, 60, 176-183. [CrossRef] [PubMed]

29. Ministry of Environment. White Paper in Environment; Ministry of Environment: Gwacheon, Korea, 2008. (In Korean)

30. Korea Environmental Policy Bulletin (Volume-Based Waste Fee System in Korea). 2006. Available online: http://eng.me.go.kr/eng/file/readDownloadFile.do;jsessionid= 5iu1EdBTzFcpz6DbuVPif7nrjNBER2UT4RZANstftx2njZsqquNXadaD0ctMEKMy.meweb1vhost_ servlet_engine3 fileId=92436\&fileSeq=1 (accessed on 4 March 2018).

31. Shiota, K.; Tsujimoto, Y.; Takaoka, M.; Oshita, K.; Fujimori, T. Emission of particulate matter from gasification and melting furnace for municipal solid waste in Japan. J. Environ. Chem. Eng. 2017, 5, 1703-1710. [CrossRef]

(C) 2018 by the authors. Licensee MDPI, Basel, Switzerland. This article is an open access article distributed under the terms and conditions of the Creative Commons Attribution (CC BY) license (http:// creativecommons.org/licenses/by/4.0/). 